\title{
Optimized Flow Sheet for a Reference Commercial- Scale Nuclear-Driven High-Temperature Electrolysis Hydrogen Production Plant
}

M. G. McKellar

J. E. O'Brien

E. A. Harvego

J. S. Herring

November 2007

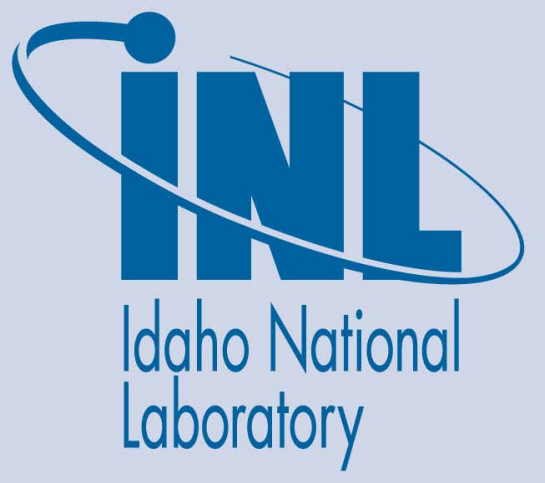

The INL is a U.S. Department of Energy National Laboratory operated by Battelle Energy Alliance 
INL/EXT-07-13573

\title{
Optimized Flow Sheet for a Reference Commercial- Scale Nuclear-Driven High-Temperature Electrolysis Hydrogen Production Plant
}

\author{
M. G. McKellar \\ J. E. O'Brien \\ E. A. Harvego \\ J. S. Herring
}

November 2007

Idaho National Laboratory
Idaho Falls, Idaho 83415

Prepared for the

U.S. Department of Energy

Office of Nuclear Energy

Under DOE Idaho Operations Office

Contract DE-AC07-05ID14517 


\section{DISCLAIMER}

This information was prepared as an account of work sponsored by an agency of the U.S. Government. Neither the U.S. Government nor any agency thereof, nor any of their employees, makes any warranty, express or implied, or assumes any legal liability or responsibility for the accuracy, completeness, or usefulness of any information, apparatus, product, or process disclosed, or represents that its use would not infringe privately owned rights. References herein to any specific commercial product, process, or service by trade name, trademark, manufacturer, or otherwise, does not necessarily constitute or imply its endorsement, recommendation, or favoring by the U.S. Government or any agency thereof. The views and opinions of authors expressed herein do not necessarily state or reflect those of the U.S. Government or any agency thereof. 


\begin{abstract}
This report presents results from the development and optimization of a reference commercialscale high-temperature electrolysis (HTE) plant for hydrogen production. The reference plant design is driven by a high-temperature helium-cooled reactor coupled to a direct Brayton power cycle. The reference design reactor power is $600 \mathrm{MWt}$, with a primary system pressure of 7.0 $\mathrm{MPa}$, and reactor inlet and outlet fluid temperatures of $540^{\circ} \mathrm{C}$ and $900^{\circ} \mathrm{C}$, respectively. The electrolysis unit used to produce hydrogen consists of $4.176 \times 10^{6}$ cells with a per-cell active area of $225 \mathrm{~cm}^{2}$. A nominal cell area-specific resistance, $A S R$, value of $0.4 \mathrm{Ohm} \cdot \mathrm{cm}^{2}$ with a current density of $0.25 \mathrm{~A} / \mathrm{cm}^{2}$ was used, and isothermal boundary conditions were assumed. The optimized design for the reference hydrogen production plant operates at a system pressure of 5.0 $\mathrm{MPa}$, and utilizes an air-sweep system to remove the excess oxygen that is evolved on the anode side of the electrolyzer. The inlet air for the air-sweep system is compressed to the system operating pressure of 5.0 $\mathrm{MPa}$ in a four-stage compressor with intercooling. The overall system thermal-to-hydrogen production efficiency (based on the low heating value of the produced hydrogen) is $49.07 \%$ at a hydrogen production rate of $2.45 \mathrm{~kg} / \mathrm{s}$ with the high-temperature helium-cooled reactor concept. The information presented in this report is intended to establish an optimized design for the reference nuclear-driven HTE hydrogen production plant so that parameters can be compared with other hydrogen production methods and power cycles to evaluate relative performance characteristics and plant economics.
\end{abstract}




\section{TABLE OF CONTENTS}

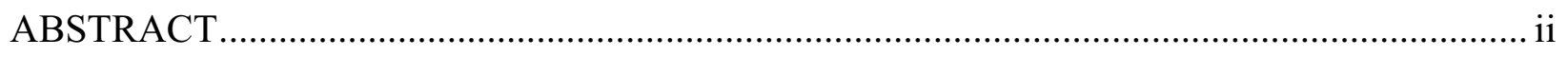

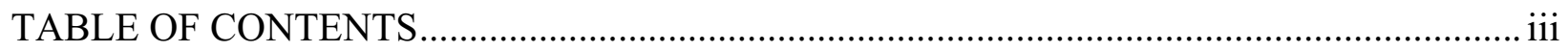

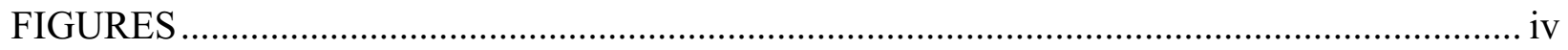

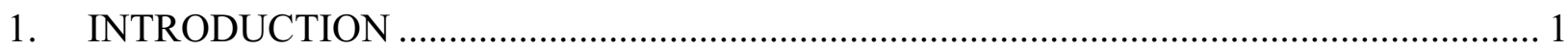

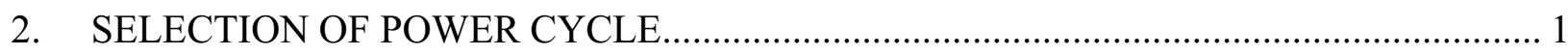

2.1. Direct Helium Recuperated Brayton Cycle ............................................................... 2

3. SELECTION OF THE REFERENCE HTE PROCESS ……............................................... 3

4. COUPLING OF THE HTE PLANT AND REACTOR POWER CYCLE .............................. 4

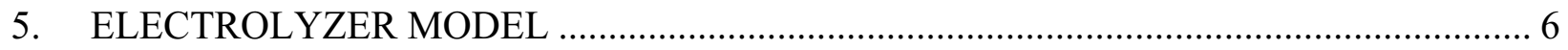

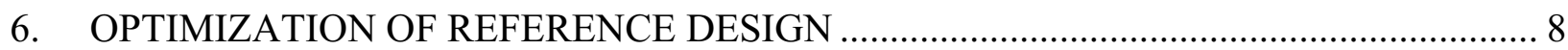

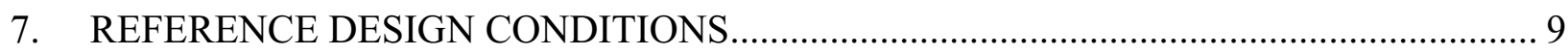

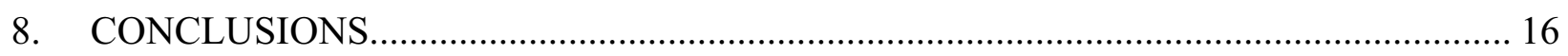

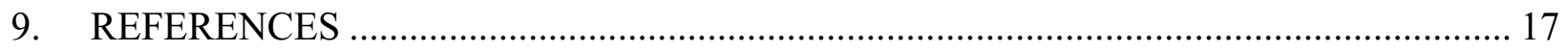




\section{FIGURES}

Figure 1. UniSim process flow diagram for helium recuperated direct Brayton cycle..............3

Figure 2. Process flow diagram for helium-cooled reactor/direct Brayton/HTE system with

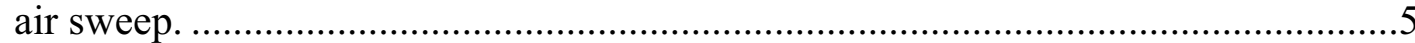

Figure 3. Process flow diagram of electrolyzer model.................................................6

Figure 4. Temperature profile plot of Brayton cycle recuperator. ..........................................13

Figure 5. Temperature profile of Intermediate Heat Exchanger. ..........................................13

Figure 6. Temperature profile of Electrolysis Heat Recuperator. .........................................14

Figure 7. Overall hydrogen product efficiency as a function of current density for an ASR of 0.4 , isothermal boundary conditions, and constant steam utilization..................15

Figure 8. Overall hydrogen production efficiency as a function of steam utilization for an ASR of 0.4 , adiabatic boundary conditions, and constant process and air sweep flows. 


\section{TABLES}

Table 1. Electrolysis fluid stream conditions and flow rates. ........................................... 7

Table 2. Mole fraction composition data for electrolysis unit. ........................................ 7

Table 3. Isothermal electrolysis reaction (88.89\% water conversion).............................. 7

Table 4. Isothermal flow and reaction balance (88.89\% water conversion)........................ 7

Table 5. Stream fluid conditions and flow rates for reference plant design. ....................... 10

Table 6. Mole fraction composition data for reference plant design ................................ 11

Table 7. Component heat rates and electrolysis power for reference design....................... 12

Table 8. Heat exchanger design parameters for reference plant design............................. 12

Table 9. Turbine design parameters for reference plant design...................................... 12

Table 10. Compressor design parameters for reference plant design. .................................. 12

Table 11. Pump design parameters for reference plant design. ......................................... 12 


\section{INTRODUCTION}

This report presents results from the development and optimization of a reference commercialscale high-temperature electrolysis (HTE) plant for hydrogen production. The primary advantage of high temperature electrolysis over conventional electrolysis, which is a well established technology, is that considerably higher overall efficiencies can be achieved. The improved performance of HTE versus conventional low-temperature (alkaline or PEM) electrolysis is due to both the improved power-cycle efficiencies and electrolyzer efficiencies associated with high-temperature operation. Higher reactor outlet temperatures yield higher power cycle efficiencies in accordance with the Carnot principle. For example, power conversion thermal efficiencies in excess of 50\% can be achieved with the high-temperature gascooled reactor coupled to the direct Brayton cycle [1]. The electrolyzer itself benefits from hightemperature operation for reasons related to both thermodynamics and kinetics. From thermodynamics, the electrical energy requirement for water or steam electrolysis decreases with increasing temperature, while the thermal energy requirement increases. Consequently, at higher temperatures, a larger fraction of the total electrolysis energy input can be supplied in the form of heat, increasing the overall process efficiency. In terms of kinetics, activation and ohmic electrochemical overpotentials also decrease dramatically with temperature.

UniSim process analysis software was used to evaluate the performance of the commercial-scale hydrogen production plant coupled to a high temperature helium cooled reactor. UniSim software is a derivative of the HYSYS process analysis software. UniSim inherently ensures mass and energy balances across all components and it includes thermodynamic data for all chemical species. The work described in this report establishes the optimized design based on analyses of process flow diagrams that include realistic representations of the reactor power source coupled to the Brayton power cycle and integrated with the high-temperature electrolysis process loops. As with previous HTE system analyses performed at the INL, a custom electrolyzer model was incorporated into the overall process flow sheet. This electrolyzer model allows for the determination of the average Nernst potential, cell operating voltage, gas outlet temperatures, and electrolyzer efficiency for any specified inlet steam, hydrogen, and sweep-gas flow rates, current density, cell active area, and external heat loss or gain. The electrolyzer model has been validated by comparison with results obtained from a fully 3-D computational fluid dynamics model and by comparison with experimental results. These comparisons may be found in Reference [3].

\section{SELECTION OF POWER CYCLE}

The selection of the reactor power cycle was based on previous parametric studies performed at the INL $[2,4]$. In these previous studies, three advanced reactor - power cycle combinations were analyzed, including: a high-temperature helium-cooled reactor coupled to a direct helium recuperated Brayton cycle, a supercritical $\mathrm{CO}_{2}$-cooled reactor coupled to a direct supercritical $\mathrm{CO}_{2}$ recompression cycle, and a sodium-cooled fast reactor coupled to a tertiary steam Rankine cycle. 
The three reactor power cycles evaluated were based on advanced reactor concepts capable of operating with reactor outlet temperatures in the range of $550^{\circ} \mathrm{C}$ to $900^{\circ} \mathrm{C}$. These high temperatures result in higher power cycle efficiencies (33 to 55\%) for these advanced reactor concepts than can be achieved with current generation light water reactors (30 to 35\%). In addition, the high temperature process heat available from these advanced high temperature reactors can further enhance hydrogen production efficiencies when the reactor is directly coupled to a HTE hydrogen production plant.

The results of these studies showed that a high-temperature gas-cooled reactor directly coupled to a helium-recuperated Brayton cycle produced higher overall thermal-to-hydrogen production efficiencies (in the range of 45 - 50\% efficiency) when compared to the supercritical CO2-cooled reactor utilizing a direct recompression power cycle ( $42-44 \%$ hydrogen production efficiency) and a sodium-cooled reactor utilizing an indirect Rankine cycle $(33-34 \%$ hydrogen production efficiency).

Based on these results, a helium-cooled high-temperature gas-cooled reactor coupled to a direct helium recuperated Brayton power cycle was selected as the reference power source. This power system is described in more detail below.

\subsection{Direct Helium Recuperated Brayton Cycle}

A process flow diagram for the high-temperature helium-cooled reactor coupled to the direct helium recuperated Brayton cycle is presented in Figure 1. This UniSim power-cycle model was initially described in [4]. The primary helium coolant exits the reactor at $900^{\circ} \mathrm{C}$. This helium flow is split at T1, with more than $85 \%$ of the flow directed toward the power cycle and the remainder directed to the intermediate heat exchanger to provide process heat to the HTE loop. Within the power-cycle loop, helium flows through the power turbine where the gas is expanded to produce electric power. The helium, at a reduced pressure and temperature, then passes through a recuperator and precooler where it is further cooled before entering the lowpressure compressor. To improve compression efficiencies, the helium is again cooled in an intercooler heat exchanger before entering the high-pressure compressor. The helium exits the high-pressure compressor at a pressure that is slightly higher than the reactor operating pressure of $7 \mathrm{MPa}$. The coolant then circulates back through the recuperator where the recovered heat raises its temperature to the reactor inlet temperature of $540^{\circ} \mathrm{C}$, completing the cycle.

Process heat for the HTE hydrogen production plant is provided by splitting the reactor coolant outlet flow into two streams, and allowing a fraction (typically less than 15\%) of the flow to pass through an intermediate heat exchanger where heat is extracted for use in the hydrogen production process. The cooler helium leaving the intermediate heat exchanger (stream 3 in Figure 1) is then returned through a circulator to the reactor inlet pressure and mixed with the primary coolant returning to the reactor. 


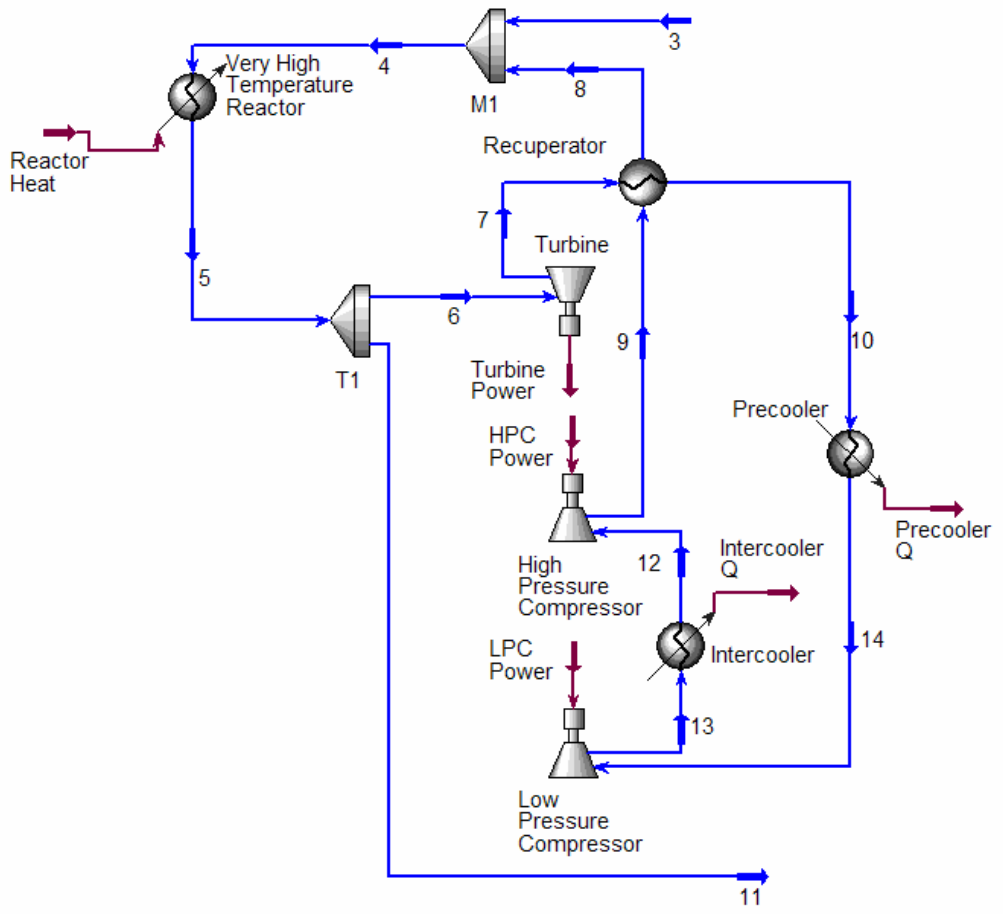

Figure 1. UniSim process flow diagram for helium recuperated direct Brayton cycle.

The reactor thermal power assumed for the high-temperature helium-cooled reactor was 600 MWt. The UniSim-calculated power cycle thermal efficiency for the system represented in Figure 1 is $53.23 \%$.

\section{SELECTION OF THE REFERENCE HTE PROCESS}

Parametric studies evaluating the coupling of various reactor concepts with the HTE hydrogen production plant are described in References [2 and 4]. These studies included operating the HTE plant at pressures of $3.5 \mathrm{MPa}$ and $7.0 \mathrm{MPa}$ and with and without the use of sweep gas to remove the excess oxygen from the anode side of the electrolyzer. An integral part of all of these parametric studies was the optimization of hydrogen production rates and efficiencies using realistic operating parameters for the various components within the system.

Based on the results of these parametric studies, a gas-sweep system was selected for the reference design. While slightly higher overall hydrogen production efficiencies $(1.0-1.5 \%)$ can be achieved when no gas sweep system is used, concerns with the handling of the high temperature oxygen product gas led to the decision to use a gas-sweep system for oxygen removal from the electrolyzer anode [2]. Two types of gas-sweep systems, an air-sweep and steam-sweep system were evaluated. The steam-sweep system was initially considered because of the relative ease of separating the steam and oxygen by condensation so that the oxygen product gas might be used for other commercial applications. However, the steam-sweep system 
unduly complicated the design of the HTE plant and individual components and, therefore, the HTE plant with an air-sweep system was selected as the reference design.

The operating pressure of the HTE plant was also evaluated because higher operating pressures result in smaller components and/or lower system pressure drops for a given mass flow rate. However, higher system pressures also require heavier and more expensive components, and can have a negative impact on system performance and reliability. Based on these considerations, and the results of analyses performed at system operating pressures of $3.5 \mathrm{MPa}$ and $7.0 \mathrm{MPa}$ which indicated slightly lower overall hydrogen production efficiencies at the higher HTE operating pressure [3], an HTE operating pressure of 5.0 MPa was selected for the reference design. The decision to operate at $5.0 \mathrm{MPa}$ was also influenced by the need to deliver the hydrogen gas at elevated pressure for either storage or pipeline transport. Therefore, from the standpoint of overall process efficiency, it is logical to compress the liquid water feedstock at the process inlet since liquid-phase compression work is very small compared to compression of the gaseous product. Any comparison made to the HTE reference process described here should also refer to delivery of the product hydrogen at 5.0 $\mathrm{MPa}$.

A description of the reference reactor power cycle and coupled HTE hydrogen production plant based on the above considerations is provided in the following section.

\section{COUPLING OF THE HTE PLANT AND REACTOR POWER CYCLE}

The overall process flow diagram for the very high-temperature helium-cooled reactor coupled to the direct helium Brayton power cycle and the HTE plant with air sweep is presented in Figure 2. The liquid water feedstock enters at the left in the diagram. The water is then compressed to the HTE process pressure of 5.0 MPa in the liquid phase using a pump.

Downstream of the pump, condensate from the water knockout tank is recycled back into the inlet stream at M3. The water stream is then vaporized and pre-heated in the electrolysis recuperator, which recovers heat from the post-electrolyzer process and sweep-gas outlet streams. Downstream of the recuperator, at $\mathrm{M} 2$, the steam is mixed with recycled hydrogen product gas. A fraction of the product gas is recycled in this way in order to assure that reducing conditions are maintained on the steam/hydrogen electrode. Downstream of the mixer, the process gas mixture enters the intermediate heat exchanger (IHX), where final heating to the electrolysis operating temperature occurs, using high-temperature process heat from the nuclear reactor. The process stream then enters the electrolyzer, where oxygen is electrolytically removed from the steam, producing hydrogen and oxygen. An additional process heater is used to directly add heat during the electrolysis process to maintain isothermal electrolyzer operating conditions. The custom electrolyzer module developed at INL for direct incorporation into the UniSim system analysis code has been described in detail previously [3]. 


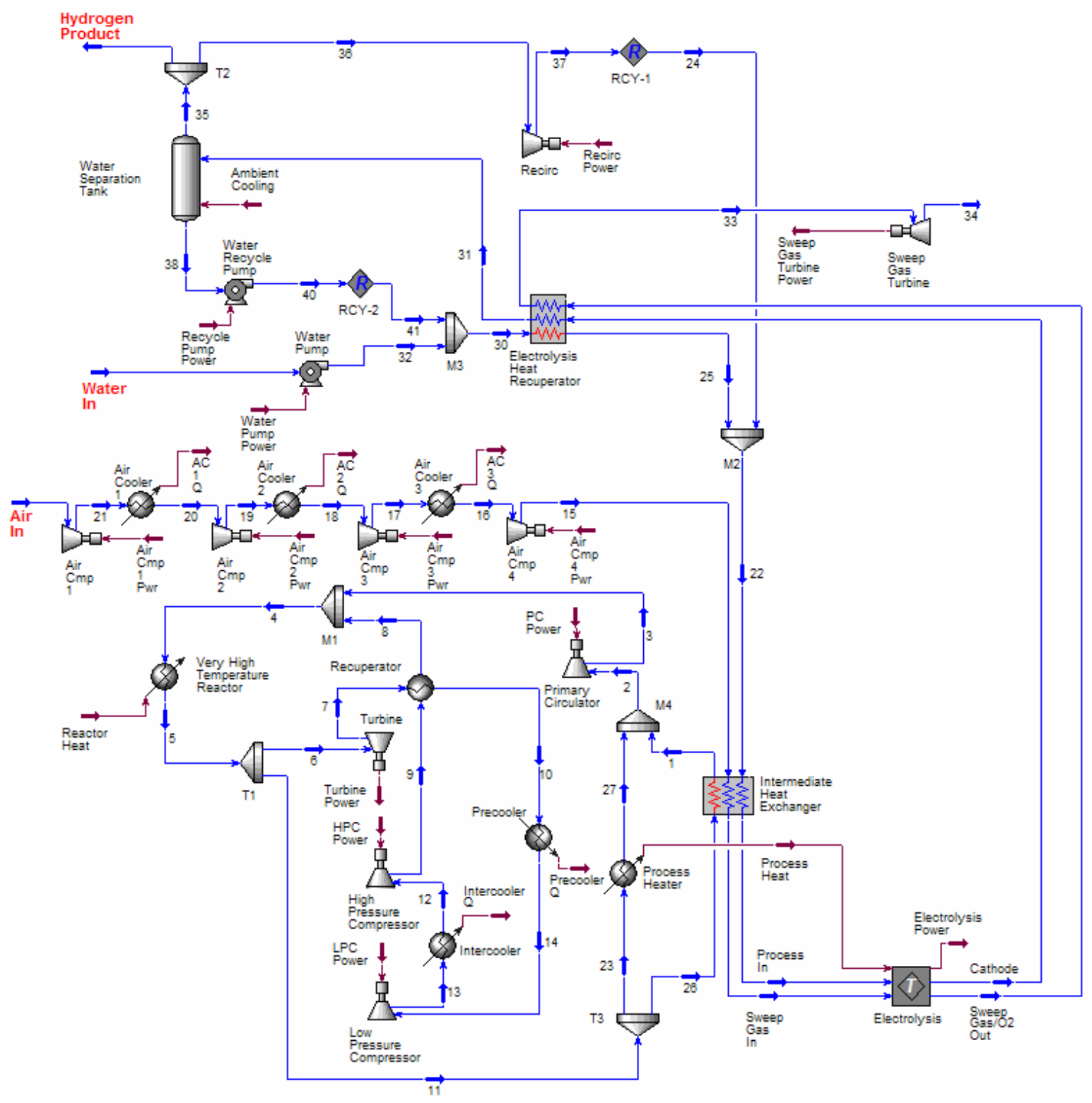

Figure 2. Process flow diagram for helium-cooled reactor/direct Brayton/HTE system with air sweep.

Downstream of the electrolyzer, the hydrogen - rich product stream flows through the electrolysis recuperator where the product stream is cooled and the inlet process stream is preheated. The product stream is cooled further at the water knockout tank, where the majority of any residual steam is condensed and separated, and yielding dry hydrogen product. The cooled product stream is split at T2 and a fraction of the product gas is recycled into the inlet process stream, as discussed previously. A recirculating blower is required to repressurize the recycle stream to the upstream pressure at M2.

The process flow diagram shows air in use as a sweep gas, to remove the excess oxygen that is evolved on the anode side of the electrolyzer. In the air sweep system, inlet air is compressed to 
the system operating pressure of 5.0 MPa in a four-stage compressor with intercooling. The final compression stage is not followed by a cooler, so the air enters the $\mathrm{IHX}$ at about $171^{\circ} \mathrm{C}$. The sweep gas is heated to the electrolyzer operating temperature of $800^{\circ} \mathrm{C}$ via the IHX which supplies high-temperature nuclear process heat directly to the system. The sweep gas then enters the electrolyzer, where it is combined with product oxygen. Finally, it passes through the electrolysis recuperator to help preheat the incoming process gas. Some of the sweep gas compression work is recovered using a sweep-gas turbine located at the sweep-gas exit.

\section{ELECTROLYZER MODEL}

The electrolyzer model process flow diagram is shown in Figure 3. The process flow consisting of steam and hydrogen passes through a conversion reactor where the steam is split into hydrogen and oxygen. The conversion reactor uses a stoichiometric equation for the splitting of water. Based upon the utilization, a specified percentage of the steam is converted. UniSim calculates the heat of reaction for this conversion, which is shown as the "Electrolysis Heating" energy stream in Figure 3. The Liquid Product stream has no flow and is really a null stream. The hydrogen, oxygen, and steam enter a component splitter labeled Electrodes. The oxygen is split from the other components and exits at anode stream. The sweep gas mixes with the anode stream and exits as the Sweep/Gas O2 Out stream. An embedded spreadsheet is used to calculate the Nernst potential, operating voltage, current and electrolysis power. In this reference case, since the boundary conditions are isothermal, the heat into the electrolysis process is also calculated.

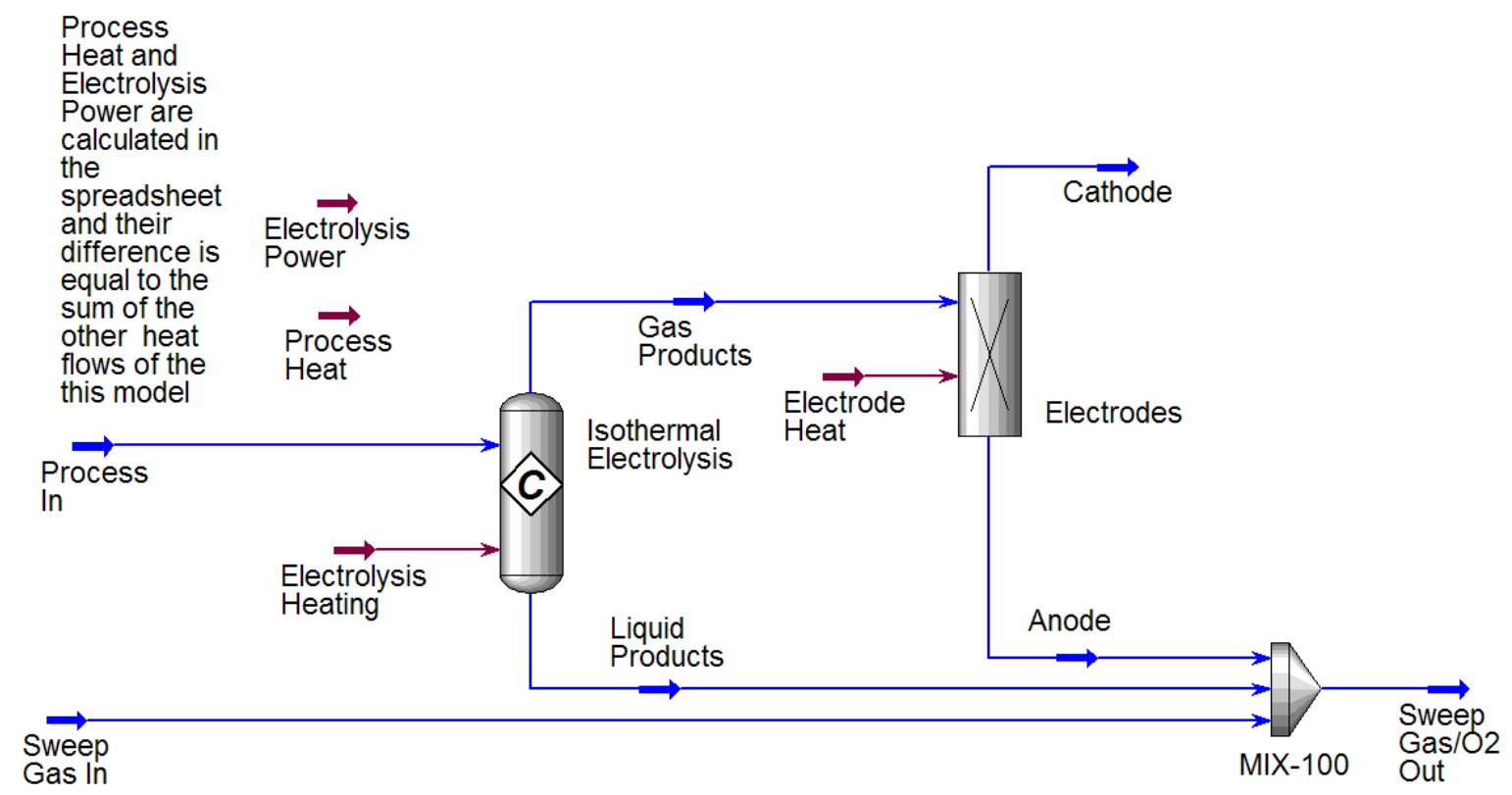

Figure 3. Process flow diagram of electrolyzer model. 
Table 1 provides the flow conditions of the streams found in Figure 3. The composition of each stream is tabulated in Table 2. Table 3 and Table 4 display the water electrolysis reaction information.

Table 1. Electrolysis fluid stream conditions and flow rates.

\begin{tabular}{|c|c|c|c|c|c|}
\hline Name & $\begin{array}{l}\text { Vapor } \\
\text { Fraction }\end{array}$ & $\begin{array}{l}\text { Temperature } \\
\text { (C) }\end{array}$ & $\begin{array}{l}\text { Pressure } \\
\text { (MPa) }\end{array}$ & $\begin{array}{l}\text { Molar } \\
\text { Flow } \\
\text { (gmole/s) }\end{array}$ & $\begin{array}{l}\text { Mass } \\
\text { Flow } \\
\text { (kg/s) }\end{array}$ \\
\hline $\begin{array}{l}\text { Process } \\
\text { In }\end{array}$ & 1 & 800 & -2 & 1521 & 24.97 \\
\hline $\begin{array}{c}\text { Sweep } \\
\text { Gas In } \\
\text { Gas }\end{array}$ & 1 & 800 & 5 & 1049 & 30.27 \\
\hline $\begin{array}{l}\text { Products } \\
\text { Liquid }\end{array}$ & 1 & 800 & 5 & 2130 & 24.97 \\
\hline $\begin{array}{c}\text { Products } \\
\text { Sweep } \\
\text { Gas/O2 }\end{array}$ & 0 & 800 & 5 & 0 & 0 \\
\hline Out & 1 & 800 & 5 & 1657 & 49.74 \\
\hline
\end{tabular}

Table 2. Mole fraction composition data for electrolysis unit.

\begin{tabular}{c|cccccc}
\hline Name & H2O & Hydrogen & Oxygen & Nitrogen & CO2 & Helium \\
$\begin{array}{c}\text { Process In } \\
\text { Sweep Gas }\end{array}$ & 0.9 & 0.1 & 0 & 0 & 0 & 0 \\
$\begin{array}{c}\text { In } \\
\text { Gas }\end{array}$ & 0 & 0 & 0.21 & 0.79 & 0 & 0 \\
$\begin{array}{c}\text { Products } \\
\text { Liquid }\end{array}$ & 0.0714 & 0.6429 & 0.2857 & 0 & 0 & 0 \\
$\begin{array}{c}\text { Products } \\
\text { Sweep }\end{array}$ & 0.0714 & 0.6429 & 0.2857 & 0 & 0 & 0 \\
Gas/O2 Out & 0 & 0 & 0.5 & 0.5 & 0 & 0 \\
Cathode & 0.1 & 0.9 & 0 & 0 & 0 & 0 \\
\hline Anode & 0 & 0 & 1 & 0 & 0 & 0
\end{tabular}

Table 3. Isothermal electrolysis reaction ( $88.89 \%$ water conversion).

\begin{tabular}{|l|cc|}
\multicolumn{1}{c}{ Component } & $\begin{array}{c}\text { Mole } \\
\text { Weight }\end{array}$ & $\begin{array}{c}\text { Stoichiometric } \\
\text { Coeff. }\end{array}$ \\
\hline Hydrogen & 2.016 & 2 \\
\hline Oxygen & 32 & 1 \\
H2O & 18.02 & -2 \\
\hline
\end{tabular}

Table 4. Isothermal flow and reaction balance ( $88.89 \%$ water conversion).

\begin{tabular}{llccc}
\hline Components & $\begin{array}{c}\text { Total } \\
\text { Inflow } \\
\text { (gmole/s) }\end{array}$ & $\begin{array}{c}\text { Total Reaction } \\
\text { (gmole/s) }\end{array}$ & $\begin{array}{c}\text { Total } \\
\text { Outflow } \\
\text { (gmole/s) }\end{array}$ \\
\hline H20 & 1369 & -1217 & 152.1 \\
Hydrogen & 152.1 & 1217 & 1369 \\
Oxygen & 0 & 608.4 & 608.4 \\
Nitrogen & 0 & 0 & 0 \\
\hline CO2 & 0 & 0 & 0 \\
Helium & 0 & 0 & 0
\end{tabular}




\section{OPTIMIZATION OF REFERENCE DESIGN}

Optimization of the reference design was performed as part of the parametric studies in Reference [2]. The methodology and constraints used in running the UniSim simulations in order to maximize hydrogen production efficiencies for the very high-temperature helium-cooled reactor coupled to the direct helium Brayton power cycle and the HTE plant were as follows:

1. Specify desired current density, inlet and outlet compositions of steam and hydrogen, cell area and total number of cells. We have specified 90\% steam, 10\% hydrogen at the inlet and $10 \%$ steam, $90 \%$ hydrogen at the outlet. This corresponds to a steam utilization of $88.9 \%$.

2. Determine the required mass flow rate of process steam based on the specified current density (and corresponding hydrogen production rate) and inlet and outlet compositions.

3. Adjust the flow split at T2 to achieve the desired inlet composition (10\% hydrogen, $90 \%$ steam)

4. For the air sweep system, the mass flow of the air is automatically adjusted to produce an outlet stream that is $50 \%$ oxygen (the remainder is nitrogen).

5. Adjust the outlet pressure of the low-pressure compressor to achieve maximum powercycle efficiency.

6. Adjust the power cycle/HTE process heat split at T1 to maximize hydrogen production efficiency until the minimum approach temperature of the electrolysis heat recuperator is just below $50^{\circ} \mathrm{C}$.

7. Assume the power cycle turbine adiabatic efficiency is $93 \%$. Power cycle compressor efficiencies are $88 \%$. All other compressor, turbine and pump efficiencies are $75 \%$.

Using the above approach, the per-cell active area for electrolysis was assumed to be $225 \mathrm{~cm}^{2}$. This cell size is well within the limits of current technology for planar cells. The total number of cells used in the reference design was determined by specifying a current density of 0.25 amperes $/ \mathrm{cm}^{2}$ for an area-specific resistance, $A S R$, value of 0.4 and assuming isothermal conditions for the electrolysis process. The number of cells was adjusted until the full power cycle output at this operating point is dedicated to electrolysis. This procedure resulted in 4.176 $\mathrm{x} 10^{6}$ cells required.

The $A S R$ value of 0.4 used in the electrolyzer model is based on the current best achievable $A S R$ for solid oxide fuel cells [5].

To allow for comparisons between the performances of the HTE process to alternate hydrogen production techniques, we have adopted a general efficiency definition that can be applied to any thermal water-splitting process, including HTE, low-temperature electrolysis (LTE), and thermochemical processes. Since the primary energy input to the thermochemical processes is in the form of heat, the appropriate general efficiency definition to be applied to all of the techniques is the overall thermal-to-hydrogen efficiency, $\eta_{H}$. This efficiency is defined as the heating value of the produced hydrogen divided by the total thermal input required to produce it. In this report, the lower heating value, LHV, of the produced hydrogen has been used: 


$$
\eta_{H}=\frac{L H V}{\sum_{i} Q_{i}}
$$

The denominator in this efficiency definition quantifies all of the net thermal energy that is consumed in the process. For a thermochemical process, this summation includes the direct nuclear process heat as well as the thermal equivalent of any electrically driven components such as pumps, compressors, etc. The thermal equivalent of any electrical power consumed in the process is the power divided by the thermal efficiency of the power cycle. For the reference helium-cooled direct Brayton cycle, the power-cycle thermal efficiency is $53.2 \%$. For the electrolysis process, the summation in the denominator of Eqn. (1) includes the thermal equivalent of the primary electrical energy input to the electrolyzer and the secondary contributions from smaller components such as pumps and compressors. In additional, any direct thermal inputs are also included. Direct thermal inputs include any net (not recuperated) heat required to heat the process streams up to the electrolyzer operating temperature and any direct heating of the electrolyzer itself required for isothermal operation. Finally, if a reactor outlet temperature is insufficient to raise the feed temperature to the desired electrolyzer operating temperature (in this case $800^{\circ} \mathrm{C}$ ), then the thermal equivalent of any auxiliary heaters must be included. If these heaters use electrical resistance heat, the heat input is penalized by the power cycle thermal efficiency. If the heaters are combustion-based, only the direct heat amount is included.

\section{REFERENCE DESIGN CONDITIONS}

Fluid conditions, flow rates, stream composition and component operating parameters for the optimized reference case are summarized in Tables 5-11 at each of the locations shown in Figure 2 . The temperature, pressure, molar and mass flow rates, and the vapor fraction for each stream are displayed in Table 5. The composition of each stream is shown in Table 6. Table 7 provides the heat rates and the electrolysis power shown in Figure 2. The thermal duty, overall heat transfer coefficient, UA, log-mean temperature difference, LMTD, and the minimum approach temperature for each heat exchanger is found in Table 8. Turbine, compressor and pump parameters are given in Tables 9-11. Figures 4, 5, and 6 show temperature versus heat flow profiles of the recuperator, IHX, and electrolysis heat recuperator heat exchangers. Figure 4 shows that the recuperator has a very tight profile. The minimum temperature difference is 17 ${ }^{\circ} \mathrm{C}$. The temperature profile of the IHX is shown in Figure 5. The cold side profile is a composite of the air sweep and the process streams. This heat exchanger has a temperature difference of $100^{\circ} \mathrm{C}$ due to the temperature difference between the outlet of the reactor, $900{ }^{\circ} \mathrm{C}$ and the electrolysis process temperature, $800^{\circ} \mathrm{C}$. The electrolysis heat recuperator profile is found in Figure 6. This profile has a minimum approach temperature of $50^{\circ} \mathrm{C}$. The cold stream is the water entering the process. The hot side is a composite of the sweep gas and the process gas after electrolysis. One can see that the water starts at a sub-cooled state and ends at a superheated state. The temperature profiles reveal that there are no temperature crossovers; therefore the heat exchangers should operate effectively. 
Table 5. Stream fluid conditions and flow rates for reference plant design.

\begin{tabular}{|c|c|c|c|c|c|}
\hline Name & $\begin{array}{c}\text { Vapor } \\
\text { Fraction }\end{array}$ & $\begin{array}{l}\text { Temperature } \\
\text { (C) }\end{array}$ & $\begin{array}{l}\text { Pressure } \\
\text { (MPa) }\end{array}$ & $\begin{array}{c}\text { Molar Flow } \\
\text { (gmole/s) }\end{array}$ & $\begin{array}{l}\text { Mass Flow } \\
(\mathrm{kg} / \mathrm{s})\end{array}$ \\
\hline Process In & 1 & 800 & 5 & 1521 & 24.97 \\
\hline Sweep Gas In & 1 & 800 & 5 & 1049 & 30.27 \\
\hline Sweep Gas/O2 Out & 1 & 800 & 5 & 1657 & 49.74 \\
\hline Cathode & 1 & 800 & 5 & 1521 & 5.5 \\
\hline 2 & 1 & 515.723 & 6.949 & 1.07E+04 & 42.73 \\
\hline 3 & 1 & 523.013 & 7.07 & $1.07 E+04$ & 42.73 \\
\hline 4 & 1 & 540 & 7.07 & $8.01 \mathrm{E}+04$ & 320.5 \\
\hline 5 & 1 & 900 & 7.019 & $8.01 \mathrm{E}+04$ & 320.5 \\
\hline 6 & 1 & 900 & 7.019 & $6.94 \mathrm{E}+04$ & 277.8 \\
\hline 7 & 1 & 560.506 & 2.763 & $6.94 E+04$ & 277.8 \\
\hline 8 & 1 & 542.613 & 7.07 & $6.94 \mathrm{E}+04$ & 277.8 \\
\hline 9 & 1 & 100.098 & 7.18 & $6.94 \mathrm{E}+04$ & 277.8 \\
\hline 10 & 1 & 117.509 & 2.713 & $6.94 \mathrm{E}+04$ & 277.8 \\
\hline 11 & 1 & 900 & 7.019 & $1.07 \mathrm{E}+04$ & 42.73 \\
\hline 12 & 1 & 26 & 4.387 & $6.94 \mathrm{E}+04$ & 277.8 \\
\hline 13 & 1 & 100.029 & 4.407 & $6.94 \mathrm{E}+04$ & 277.8 \\
\hline 14 & 1 & 26 & 2.693 & $6.94 \mathrm{E}+04$ & 277.8 \\
\hline 15 & 1 & 170.566 & 5.035 & 1049 & 30.27 \\
\hline 16 & 1 & 46.85 & 2.034 & 1049 & 30.27 \\
\hline 17 & 1 & 176.85 & 2.054 & 1049 & 30.27 \\
\hline 18 & 1 & 46.85 & 0.7962 & 1049 & 30.27 \\
\hline 19 & 1 & 176.85 & 0.8047 & 1049 & 30.27 \\
\hline 20 & 1 & 46.85 & 0.3117 & 1049 & 30.27 \\
\hline 21 & 1 & 176.85 & 0.3147 & 1049 & 30.27 \\
\hline Air In & 1 & 26.85 & 0.1013 & 1049 & 30.27 \\
\hline 22 & 1 & 317.954 & 5.035 & 1521 & 24.97 \\
\hline 25 & 1 & 344.319 & 5.035 & 1369 & 24.66 \\
\hline 30 & 0 & 17.0668 & 5.07 & 1369 & 24.66 \\
\hline 32 & 0 & 15.9666 & 5.07 & 1219 & 21.96 \\
\hline Water In & 0 & 15.5556 & 0.1013 & 1219 & 21.96 \\
\hline 31 & 0.9102 & 80.3227 & 4.965 & 1521 & 5.5 \\
\hline 33 & 1 & 148.147 & 4.965 & 1657 & 49.74 \\
\hline 34 & 1 & -66.032 & 0.1013 & 1657 & 49.74 \\
\hline 36 & 1 & 26 & 4.965 & 152.2 & 0.3089 \\
\hline 37 & 1 & 27.6446 & 5.035 & 152.2 & 0.3089 \\
\hline 38 & 0 & 26 & 4.965 & 151 & 2.72 \\
\hline Hydrogen Product & 1 & 26 & 4.965 & 1218 & 2.472 \\
\hline 40 & 0 & 26.0091 & 5.07 & 151 & 2.72 \\
\hline 41 & 0 & 26.0091 & 5.07 & 150 & 2.703 \\
\hline 35 & 1 & 26 & 4.965 & 1370 & 2.781 \\
\hline 24 & 1 & 27.6446 & 5.035 & 152.2 & 0.3089 \\
\hline 1 & 1 & 515.723 & 6.949 & 6387 & 25.57 \\
\hline 23 & 1 & 900 & 7.019 & 4287 & 17.16 \\
\hline 26 & 1 & 900 & 7.019 & 6387 & 25.57 \\
\hline 27 & 1 & 515.723 & 6.949 & 4287 & 17.16 \\
\hline
\end{tabular}


Table 6. Mole fraction composition data for reference plant design

\begin{tabular}{|c|c|c|c|c|c|c|}
\hline Name & $\mathrm{H} 2 \mathrm{O}$ & Hydrogen & Oxygen & Nitrogen & $\mathrm{CO} 2$ & Helium \\
\hline Process In & 0.9 & 0.1 & 0 & 0 & 0 & 0 \\
\hline Sweep Gas In & 0 & 0 & 0.21 & 0.79 & 0 & 0 \\
\hline Sweep Gas/O2 Out & 0 & 0 & 0.5 & 0.5 & 0 & 0 \\
\hline Cathode & 0.1 & 0.9 & 0 & 0 & 0 & 0 \\
\hline 2 & 0 & 0 & 0 & 0 & 0 & 1 \\
\hline 3 & 0 & 0 & 0 & 0 & 0 & 1 \\
\hline 4 & 0 & 0 & 0 & 0 & 0 & 1 \\
\hline 5 & 0 & 0 & 0 & 0 & 0 & 1 \\
\hline 6 & 0 & 0 & 0 & 0 & 0 & 1 \\
\hline 7 & 0 & 0 & 0 & 0 & 0 & 1 \\
\hline 8 & 0 & 0 & 0 & 0 & 0 & 1 \\
\hline 9 & 0 & 0 & 0 & 0 & 0 & 1 \\
\hline 10 & 0 & 0 & 0 & 0 & 0 & 1 \\
\hline 11 & 0 & 0 & 0 & 0 & 0 & 1 \\
\hline 12 & 0 & 0 & 0 & 0 & 0 & 1 \\
\hline 13 & 0 & 0 & 0 & 0 & 0 & 1 \\
\hline 14 & 0 & 0 & 0 & 0 & 0 & 1 \\
\hline 15 & 0 & 0 & 0.21 & 0.79 & 0 & 0 \\
\hline 16 & 0 & 0 & 0.21 & 0.79 & 0 & 0 \\
\hline 17 & 0 & 0 & 0.21 & 0.79 & 0 & 0 \\
\hline 18 & 0 & 0 & 0.21 & 0.79 & 0 & 0 \\
\hline 19 & 0 & 0 & 0.21 & 0.79 & 0 & 0 \\
\hline 20 & 0 & 0 & 0.21 & 0.79 & 0 & 0 \\
\hline 21 & 0 & 0 & 0.21 & 0.79 & 0 & 0 \\
\hline Air In & 0 & 0 & 0.21 & 0.79 & 0 & 0 \\
\hline 22 & 0.9 & 0.1 & 0 & 0 & 0 & 0 \\
\hline 25 & 1 & 0 & 0 & 0 & 0 & 0 \\
\hline 30 & 1 & 0 & 0 & 0 & 0 & 0 \\
\hline 32 & 1 & 0 & 0 & 0 & 0 & 0 \\
\hline Water In & 1 & 0 & 0 & 0 & 0 & 0 \\
\hline 31 & 0.1 & 0.9 & 0 & 0 & 0 & 0 \\
\hline 33 & 0 & 0 & 0.5 & 0.5 & 0 & 0 \\
\hline 34 & 0 & 0 & 0.5 & 0.5 & 0 & 0 \\
\hline 36 & 0.0008 & 0.9992 & 0 & 0 & 0 & 0 \\
\hline 37 & 0.0008 & 0.9992 & 0 & 0 & 0 & 0 \\
\hline 38 & 0.9999 & 0.0001 & 0 & 0 & 0 & 0 \\
\hline Hydrogen Product & 0.0008 & 0.9992 & 0 & 0 & 0 & 0 \\
\hline 40 & 0.9999 & 0.0001 & 0 & 0 & 0 & 0 \\
\hline 41 & 0.9999 & 0.0001 & 0 & 0 & 0 & 0 \\
\hline 35 & 0.0008 & 0.9992 & 0 & 0 & 0 & 0 \\
\hline 24 & 0.0008 & 0.9992 & 0 & 0 & 0 & 0 \\
\hline 1 & 0 & 0 & 0 & 0 & 0 & 1 \\
\hline 23 & 0 & 0 & 0 & 0 & 0 & 1 \\
\hline 26 & 0 & 0 & 0 & 0 & 0 & 1 \\
\hline 27 & 0 & 0 & 0 & 0 & 0 & 1 \\
\hline
\end{tabular}


Table 7. Component heat rates and electrolysis power for reference design.

\begin{tabular}{|c|c|}
\hline Name & Heat Flow (kW) \\
\hline Process Heat & $3.43 \mathrm{E}+04$ \\
\hline Reactor Heat & $6.00 \mathrm{E}+05$ \\
Intercooler Q & $1.07 \mathrm{E}+05$ \\
Precooler Q & $1.32 \mathrm{E}+05$ \\
AC 3 Q & 4134 \\
\hline AC 2 Q & 4083 \\
\hline AC 1 Q & 4062 \\
Ambient Cooling & -3370 \\
Electrolysis Power & $-2.69 \mathrm{E}+05$ \\
\hline
\end{tabular}

Table 8. Heat exchanger design parameters for reference plant design.

\begin{tabular}{ccccc} 
Name & $\begin{array}{c}\text { Duty } \\
(\mathbf{k W})\end{array}$ & $\begin{array}{c}\text { UA } \\
(\mathbf{W} / \mathbf{C})\end{array}$ & $\begin{array}{c}\text { LMTD } \\
(\mathbf{C})\end{array}$ & $\begin{array}{c}\text { Minimum Approach } \\
(\mathbf{C})\end{array}$ \\
\cline { 2 - 5 } $\begin{array}{c}\text { Recuperator } \\
\text { Intermediate Heat }\end{array}$ & $-6.40 \mathrm{E}+05$ & $3.62 \mathrm{E}+07$ & 17.7 & 17.41 \\
$\begin{array}{c}\text { Exchanger } \\
\text { Electrolysis Heat } \\
\text { Recuperator }\end{array}$ & $5.11 \mathrm{E}+04$ & $3.14 \mathrm{E}+05$ & 162.6 & 100 \\
& $7.44 \mathrm{E}+04$ & $6.39 \mathrm{E}+05$ & 116.4 & 50
\end{tabular}

Table 9. Turbine design parameters for reference plant design.

\begin{tabular}{|c|c|c|c|}
\hline Name & $\begin{array}{l}\text { Adiabatic } \\
\text { Efficiency }\end{array}$ & Polytropic Efficiency & Power (kW) \\
\hline Turbine & 93 & 92 & $4.91 E+05$ \\
\hline Sweep Gas Turbine & 75 & 62 & $1.01 \mathrm{E}+04$ \\
\hline
\end{tabular}

Table 10. Compressor design parameters for reference plant design.

\begin{tabular}{|c|cc|}
\hline Name & Adiabatic Efficiency & Power (kW) \\
\hline $\begin{array}{c}\text { Primary Circulator } \\
\text { High Pressure } \\
\text { Compressor }\end{array}$ & 75 & 1622 \\
Low Pressure & 88 & $1.07 \mathrm{E}+05$ \\
Compressor & & \\
Air Cmp 4 & 88 & $1.07 \mathrm{E}+05$ \\
Air Cmp 3 & 75 & 3851 \\
Air Cmp 2 & 75 & 4047 \\
Air Cmp 1 & 75 & 4048 \\
\hline Recirc & 75 & 4661 \\
\hline
\end{tabular}

Table 11. Pump design parameters for reference plant design.

\begin{tabular}{|c|ccc|}
\hline Name & $\begin{array}{c}\text { Adiabatic } \\
\text { Efficiency (\%) }\end{array}$ & Power (kW) & Pressure Head (m) \\
\hline Water Pump & 75 & 143.4 & 499.5 \\
\hline Water Recycle Pump & 75 & 0.3778 & 10.62 \\
\hline
\end{tabular}




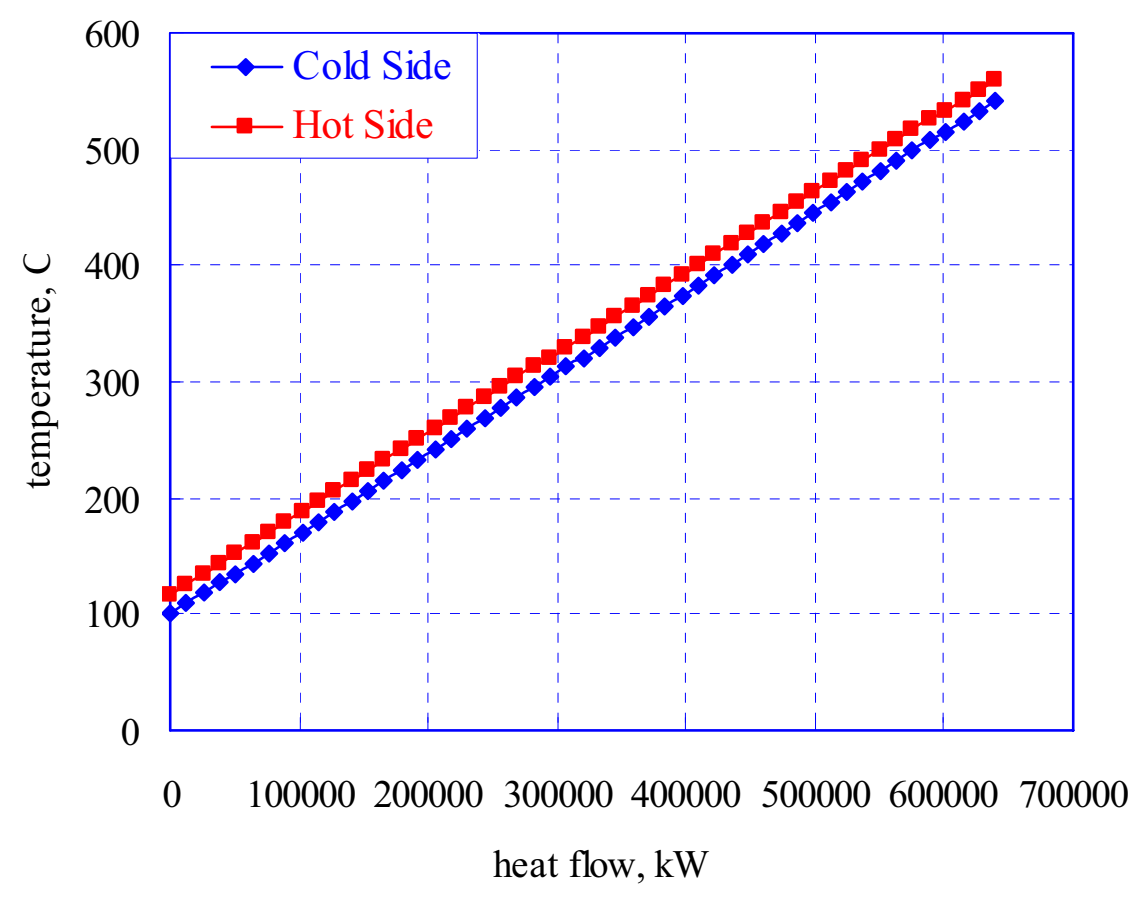

Figure 4. Temperature profile plot of Brayton cycle recuperator.

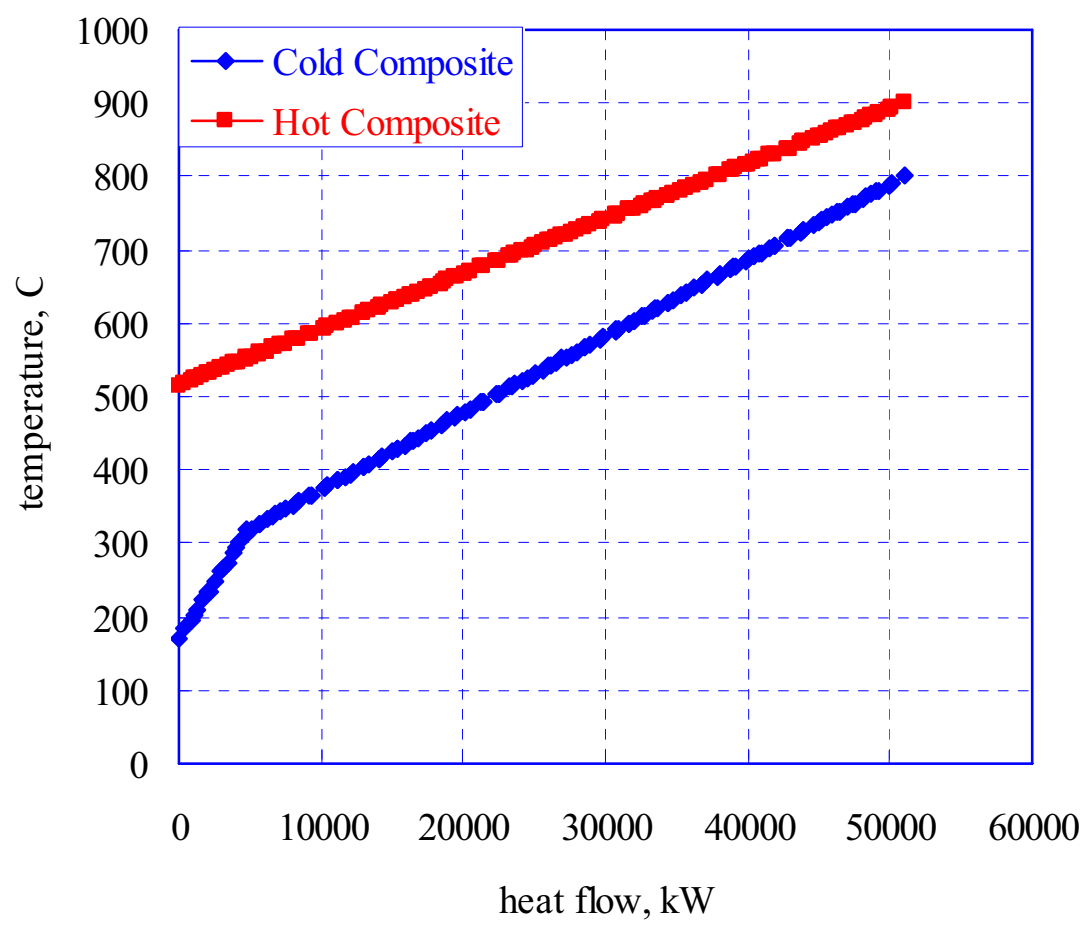

Figure 5. Temperature profile of Intermediate Heat Exchanger. 


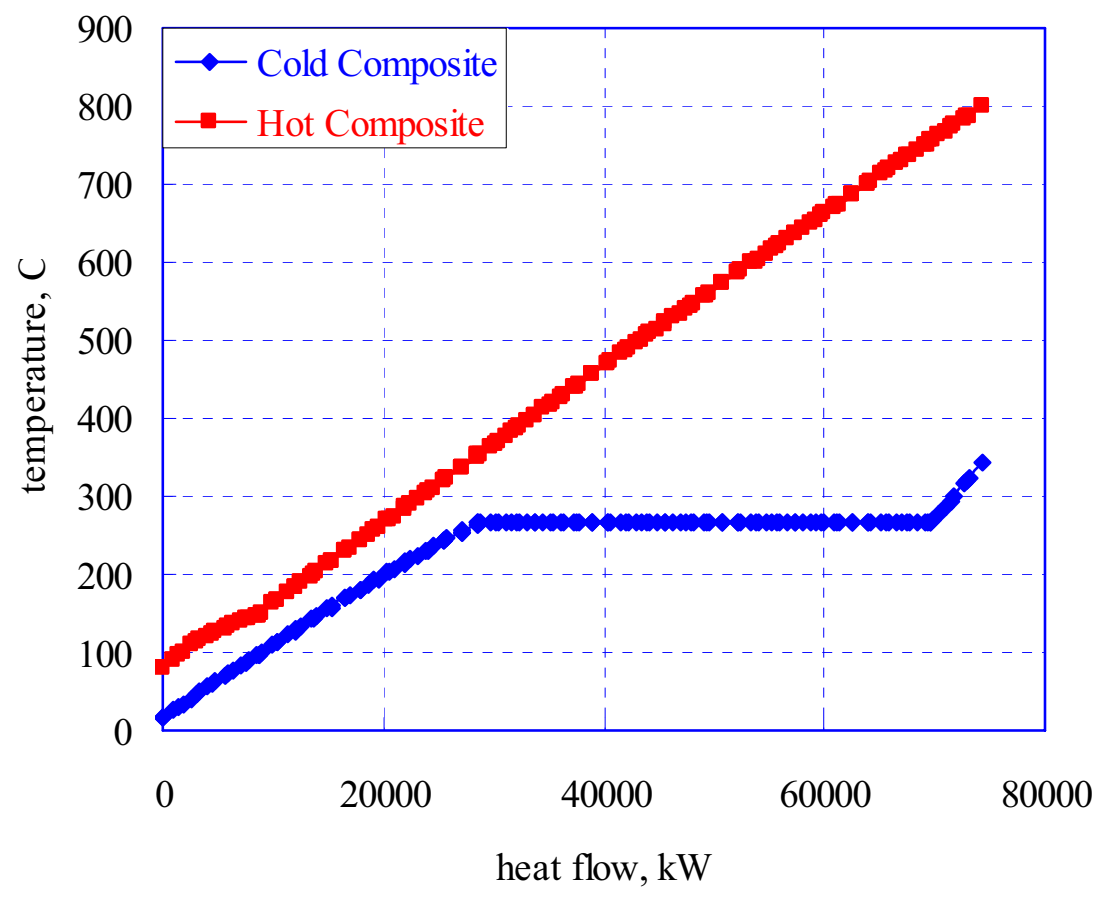

Figure 6. Temperature profile of Electrolysis Heat Recuperator.

A parametric study was also performed using the reference model. In one study, the current density was adjusted while keeping the steam utilization constant at $88.9 \%$. This study also kept the electrolysis process isothermal thus requiring direct heat from the reactor if the current density is below thermal neutral or heat rejection from the electrolysis process if the current density is above thermal neutral. Figure 7 is a plot of the resulting overall hydrogen production efficiency as a function of the hydrogen production rate (top axis) or the current density (bottom axis). As can be seen in the figure, the hydrogen production rate has a direct relationship to the current density given a constant cell area and number of cells. The overall hydrogen production efficiency increases as the current density decreases which also corresponds to a decrease in the hydrogen production rate.

A second parametric study was performed by setting the process and air sweep flow rates constant, which results in variable steam utilization. In this study, adiabatic boundary conditions were set with respect to the electrolysis process. The current density was again adjusted. Figure $\mathbf{8}$ shows the overall hydrogen production efficiency as a function of the steam utilization. As the current density decreases, the steam utilization decreases because the process stream flow rate remains constant. Lower current density means less steam is converted to hydrogen and oxygen for a given flow rate of water. Figure 8 shows that at lower steam utilization, the overall hydrogen production efficiency decreases rapidly, especially below about $40 \%$ utilization. 


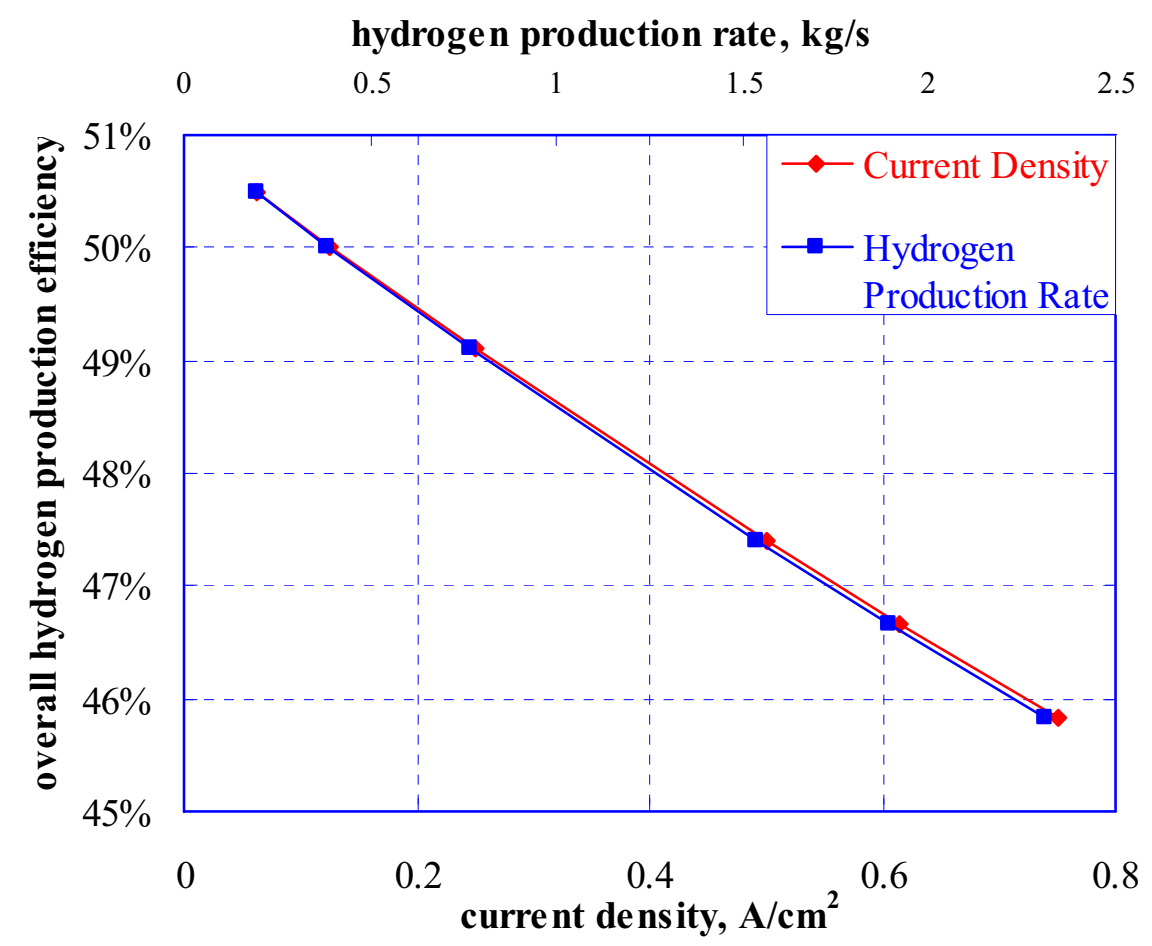

Figure 7. Overall hydrogen product efficiency as a function of current density for an ASR of 0.4 , isothermal boundary conditions, and constant steam utilization.

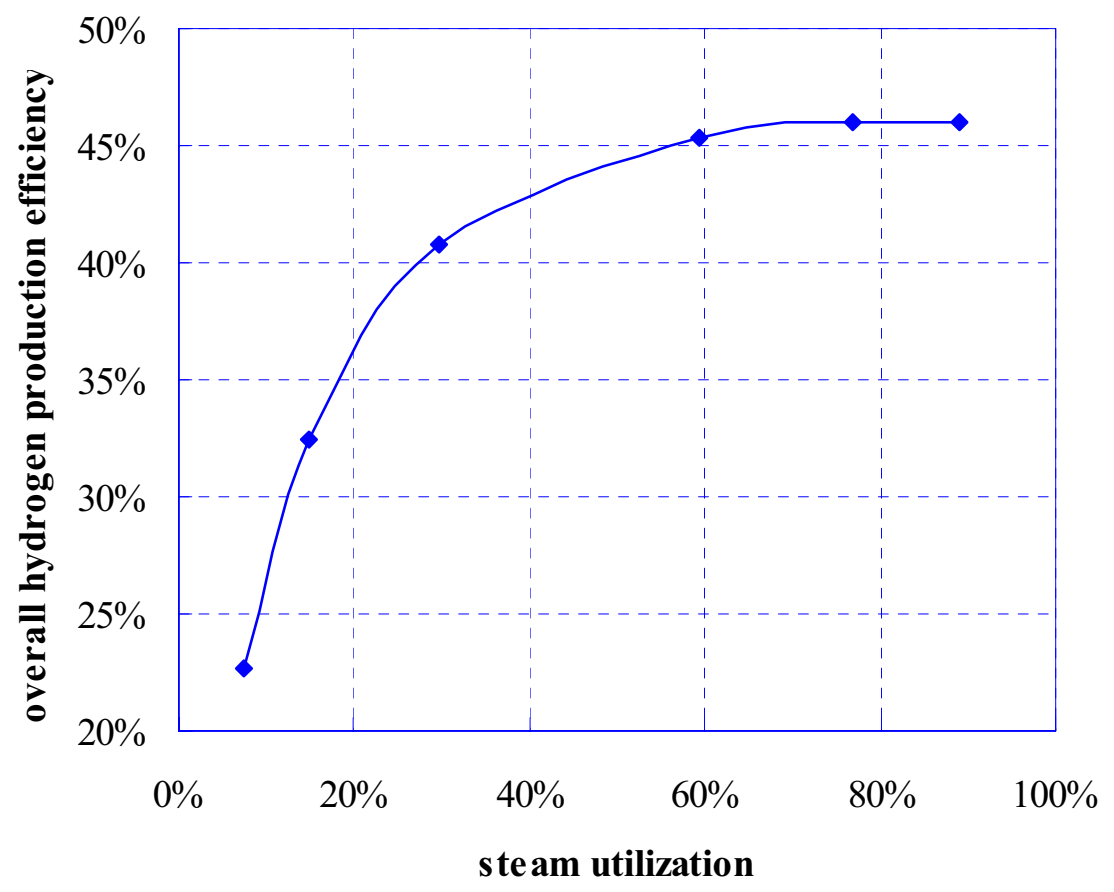

Figure 8. Overall hydrogen production efficiency as a function of steam utilization for an ASR of 0.4, adiabatic boundary conditions, and constant process and air sweep flows. 


\section{CONCLUSIONS}

This report presents results from the optimization of a reference commercial-scale hightemperature electrolysis (HTE) plant for hydrogen production. The reference HTE plant is driven by a $600 \mathrm{MWt}$ high-temperature helium-cooled reactor coupled to a direct Brayton power cycle with a reactor outlet temperature of $900^{\circ} \mathrm{C}$. The reference plant optimization is based on previous parametric studies performed using the UniSim process analysis software $[3,4]$.

The reference plant simulation was performed for a cell area-specific resistance value of 0.4 $\mathrm{Ohm} \cdot \mathrm{cm}^{2}$. The $A S R$ value of 0.4 represents a stack-average ASR value that should be achievable in the short term with existing technology. Isothermal operation of the electrolyzer was assumed. An air sweep system is also included in the reference design to remove oxygen from the anode side of the electrolyzer because of concerns with handling of the high-temperature oxygen product gas. Predicted overall thermal-to-hydrogen efficiency values for the reference design with an air-sweep system resulted in hydrogen production efficiencies that were only 1.0 -1.5 percentage points lower than the equivalent design with no sweep-gas system [2]. The operating pressure of 5.0 MPa for the HTE process loop was selected to be consistent with the need to deliver the hydrogen product gas at elevated pressures for storage or pipeline transport. This pressure also represents a trade off between the need for larger components at lower pressures and the need for more massive components for pressure containment at higher pressures.

The simulation for the reference HTE plant coupled to the helium recuperated Brayton cycle indicated a power-cycle thermal efficiency of 53.2\%. Earlier parametric studies predicted overall hydrogen production efficiencies in the 45 - 50\% range depending on the assumed current density [2]. These same studies also indicated that for adiabatic operation of the electrolyzer, a nonlinear decrease in overall hydrogen production efficiency occurred with increasing current density, as a result of the temperature-dependent $A S R$ used in the simulation.

The information presented in this report is intended to establish an optimized design for the reference nuclear-driven HTE hydrogen production plant so that parameters can be compared with other hydrogen production methods and power cycles to evaluate relative performance characteristics and plant economics. 


\section{REFERENCES}

1. Herranz, L. E., Linares, J. I., and Moratilla, B. Y., “Assessment of regenerative reheating in direct Brayton power cycles for high-temperature gas-cooled reactors," Nuclear Technology, v 159, n 1, July, 2007, pp. 15-24.

2. McKellar, M. G., O’Brien, J. E., Herring, J. S., “Commercial Scale Performance Predictions for High-Temperature Electrolysis Plants Coupled to Three Advanced Reactor Types", INL Internal Report, September 14, 2007.

3. O’Brien, J. E., Stoots, C. M., and Hawkes, G. L., "Comparison of a One-Dimensional Model of a High-Temperature Solid-Oxide Electrolysis Stack with CFD and Experimental Results," Proceedings, 2005 ASME International Mechanical Engineering Congress and Exposition, Nov. 5 - 11, Orlando.

4. Harvego, E. A., McKellar, M. G., O’Brien, J. E., and Herring, J. S., "Summary of ReactorCoupled HTE Modeling Sensitivity Studies,” DOE Milestone Report, October 26, 2006.

5. Surdoval, Wayne, Nuclear Hydrogen Initiative Semiannual Program Review, October 24, 2007, Red Lion Hotel, Idaho Falls, Idaho. 